\title{
Optimization of The Government Supervision in the Provision of the Infrastructure, Facilities, and Utility for Housing Developers in Banjarbaru City
}

\author{
Achmad Bunyani*, Samahuddin Muharram, Ahmad Yunani \\ Master of Science Development Administration, Lambung Mangkurat University, Indonesia
}

DOI: $10.36348 /$ sjef.2019.v03i11.004

| Received: 09.11.2019 | Accepted: 16.11.2019 | Published: 19.11.2019

*Corresponding author: Achmad Bunyani

\section{Abstract}

This study is purposed to describe the role of the government in overseeing the availability of infrastructure, facilities, and public utilities is very important for the convenience and survival of the people. This research method is carried out with descriptive qualitative methods that analyze and describe the availability of infrastructure, facilities, public utilities that exist in housing based on the facts that appear and as they are adjusted to government policies in the form of regional regulations governing the implementation of housing and settlements. Objects the research is the Banjarbaru Housing and Settlement Service, the Public Works and Spatial Office and Building Supervision of Banjarbaru City, the Regional Board of Indonesian Real Estate of South Kalimantan, the Banjarbaru City Central Bureau of Statistics, several Housing Developers, especially the existing home builders in the Banjarbaru City area, the head of the neighborhood association of each housing used as the respondent in the study. The results of this study are that there are still many community complaints related to the availability of infrastructure, facilities and housing utilities. It is clearly visible in the field of unavailability of sewerage channels or infiltration wells, lack of availability of drainage channels, and other facilities which are basic and basic things that must be provided by housing developers. The less optimal supervision of the Banjarbaru City government through housing and settlement services has a real impact that greatly affects the comfort of the housing environment so that a decent house that has been expected by the community as consumers cannot be fulfilled.

Keywords: government oversight, infrastructure, facilities, housing utilities.

Copyright @ 2019: This is an open-access article distributed under the terms of the Creative Commons Attribution license which permits unrestricted use, distribution, and reproduction in any medium for non-commercial use (NonCommercial, or CC-BY-NC) provided the original author and source are credited.

\section{INTRODUCTION}

Banjarbaru City experienced 2 regional splits after becoming an autonomous region, most recently with the Banjarbaru City Regulation No. 4 of 2007 concerning the Division and Formation of two New Districts in the City of Banjarbaru. Subdistrict expansion took place in the District of Landasan Ulin into the District of Landasan Ulin and the District of Liang Anggang, and the District of Banjarbaru was divided into the Districts of North Banjarbaru and the District of South Banjarbaru. Administratively, Banjarbaru City consists of 5 subdistricts with 20 villages, namely North Banjarbaru Subdistrict, South Banjarbaru Subdistrict, Landasan Ulin Subdistrict, Liang Anggang Subdistrict and Cempaka Subdistrict. The five sub-districts besides functioning as the center of government are also the centers of growth in the City of Banjarbaru. The sub-districts that have the most rapid development are the Banjarbaru District (Banjarbaru Utara and Banjarbaru Selatan) as centers of government, higher education services, public and social services, regional transportation, trade and services, and special military areas; Landasan Ulin Subdistrict (Landasan Ulin and Liang Anggang) as a regional transportation service center, industrial development center, residential development and recreation area, and Cempaka District as a center for traditional diamond mining, settlement development, reserve land and conservation.

The last decade the development of the City of Banjarbaru can be seen from the construction of shopping centers, shopping complexes, public spaces, thematic villages, without exception housing complexes. Housing complex is a vital need for the community. Therefore, the need for infrastructure, facilities and public utilities. Ideally, the forms of housing/settlement infrastructure, facilities and utilities such as roads, public open spaces, drainage canals, clean water, electricity, health facilities, school facilities 
are an integral part of quality settlement planning. Goheen [1] and Platinga [2] state that the structure and distribution of the PSU are forming residential space structures, while determining the increase in the value of environmental property as a community asset [3, 4]. Its availability and distribution largely determines the quality of the environment and the quality of life of people [5].

Housing is a group of houses that forms a single unit and functions as a residence or residential environment, equipped with infrastructure and facilities, as well as in accordance with the existing location, to support the activities of the active community in it. Based on Law No. 1 of 2011 concerning Housing and Settlement Areas, Housing is a collection of houses as part of housing in an area either urban or rural, which is equipped with infrastructure, facilities, and public utilities as a result of efforts to fulfill decent homes.

The house is a basic human need after food and clothing needs. Every individual tries to meet the needs of the home in accordance with the wishes and abilities. Besides functioning as a protector against natural or weather disturbances and other creatures, the house also has a socio-cultural role as a center for family education, cultural nursery and life values and as a manifestation of identity. In the framework of the ecological relationship between humans and their environment, it is clear that the quality of human resources in the future is greatly influenced by the quality of housing and settlements. At this time the effort to handle housing is emphasized by the developer. However, this leaves some problems.

The problem found is related to the community's complaints, whether seen from the drainage system, security, cleanliness, and so on. Intervention from the government is needed so that people can enjoy infrastructure, facilities and public utilities. Thus, this article aims to describe the role of government in overseeing the availability of infrastructure, facilities and public utilities to be very important for the comfort and survival of its people.

\section{METHODS}

The research approach refers to the principle of qualitative descriptive research that seeks to describe the phenomena that occur explaining the relationship between factors and drawing conclusions based on the analysis of data obtained [6]. Such an approach is considered relevant to describe how the condition of Banjarbaru especially in the supervision of housing construction in the availability of infrastructure facilities, public facilities and utilities [7]. The phenomenon in question is the extent to which government supervision in the availability of infrastructure, facilities, and public utilities of decent and simple housing for the people in the Banjarbaru City area so that infrastructure, facilities and public utilities that have been regulated by the government are available to the community.

The data collection technique is done in three steps; 1) observation to several housing locations that build modest housing in the Banjarbaru City area and the Housing and Settlement Office of the Oversight Section, 2) interviews with resource persons, namely the head of the neighborhood association in housing, Kelurahan, the Housing and Settlement Office of the Supervision Section, as well as the Public Works Office and Spatial Planning Section Spatial Planning, and 3) related documentation on Government Oversight, Housing, Infrastructure, facilities, housing utilities by collecting important records related to the problem under study. The study was conducted for 2 months starting with data searching until completion. Researchers took the location in the Banjarbaru City area which is the location of a simple housing development. The focus of analysis on the Department of Housing and Settlements of the City of Banjarbaru is the head of the housing and settlements department, the head of the housing sector, the head of the housing sector, the Regional Leadership Board of the Indonesian Real Estate in South Kalimantan, the Central Statistics Agency of Banjarbaru City, a number of Housing Developers (developers) especially the builders of simple houses that in the Banjarbaru City area, the Chairperson of a neighboring neighborhood in each housing area that was used as a study.

\section{RESULTS AND DISCUSSION}

Housing in Banjarbaru continues to increase every year this is due to the transfer of the government center of South Kalimantan from Banjarmasin to Banjarabaru as well as the population itself, therefore a good and optimal arrangement and supervision in regulating housing development so as not to harm the community as consumers housing and the city government as a development facilitator. Government supervision, both directly and indirectly, must be optimized so that complaints and reports from the public regarding the unavailability of housing infrastructure, facilities and utilities can be minimized.

Direct supervision carried out by government officials in the field is less than optimal due to the lack of available human resources, the need for additional human resources in charge of supervising development in the field is very important, supervision will be more effective and efficient if the government apparatus in the villages and sub-districts can also optimize more supervision housing developers by actively and periodically monitoring the spaciousness which then makes a report that can be reported directly to the supervisor or the housing and settlement department of the building supervision section.

Government apparatuses working actively in the field should be given additional incentives from the 
government for their performance in maintaining and overseeing housing development arrangements in Banjarbaru, incentives can also be given to government apparatuses from the level of the neighborhood, subdistrict and sub-district officials who actively monitor and maintain development with reports and concrete actions taken so that complaints and public reporting related to housing infrastructure, facilities and utilities can be accommodated.

Indirect supervision is carried out by following up on every report and complaint from the community at Wengga and Benawa Raya housing related to the unavailability of infrastructure, facilities, and public utilities, reports from field supervisors, both oral and written, can be accommodated for good development implementation. Forms of preventive supervision already exist in the housing and settlement department in the form of licensing pamphlets that exist on the walls of the room as well as regional regulations governing the administration of housing and settlements in Banjarbaru.

In local regulations regarding the implementation of housing, the availability of Infrastructure, Facilities, and Public Utilities for housing developers is a must for the safety and comfort of the community as consumers. In fact there are still many housing developers (developers) who are not responsible for not providing or only partial Infrastructure, Facilities, Public Utilities are met. In the field of sewerage research in the field is not provided by the developer, all housing is not provided by the developer, if there are also residents who have sewerage or sewage absorption wells because the awareness of the community itself makes their own recharge wells that are not wants to dispose of its waste in a drainage channel intended for rainwater drainage. For people who do not know or do not care about the environment around them, they usually dispose of household waste as a result of washing clothes, food, and shower drainage which can cause environmental pollution and unpleasant odors.

Drainage channel is arguably not fulfilled only part of housing which has decent and good drainage channel. The housing builders make drainage channels only in the form of earthworks, not covered with concrete frames so that when it rains the drainage channels will cover the ground again, for residents who are concerned and aware they are making their own drainage channels better. The neighborhood committee must proactively report to the city government through the housing and settlement department and the apparatus in the villages and districts. Over time the drainage channel is not available by the housing developer (developer) will be the responsibility of the government in providing the drainage channel, this also becomes homework for the government related to development priorities.
The community in general urges the government to immediately provide assistance in providing infrastructure, facilities, public utilities, in this case the government will give priority which assistance will be given first and this takes a long time, such as in Wengga housing with a period of more than 12 years and 4 times the replacement of the neighborhood committee and several times the proposal to the new government they got the body of the drainage channel from the city government of Banjarbaru. The weak repressive supervision from the government does not cause a deterrent effect on housing developers, firmness in enforcing regional regulations by enforcing administrative and criminal sanctions must be carried out. The form of administrative sanctions in regional regulation No. 8 of 2014 concerning housing and settlement implementation is

- Written warning;

- The suspension of permits is accompanied by the temporary suspension of development activities

- Revocation of license;

- Orders to demolish buildings;

- Closing location

Internal supervision carried out by the housing and settlement service carried out by the head of the housing and settlement service through the head of the housing sector as the leader in housing supervision provides input and assists the leadership in carrying out its functions. Field supervisors in carrying out their duties and functions are directed and regulated by their superiors, namely the section head of structuring, building supervision and advertisement so that the housing infrastructure, facilities and public utilities can be provided by the housing developer by actively reviewing the spaciousness in which housing is built and expressly giving sanctions administrative to fraudulent housing developers so that public complaints can be reduced.

External supervision carried out by the ministry of public works and public housing through the directorate general of housing provision by contributing stimulant assistance for infrastructure, facilities and public housing utilities to housing developers and the work of procuring infrastructure, facilities and public utilities in the housing environment for the community carried out by developers (developers) who concerned. The success of the monitoring program itself can be seen from various indicators as follows:

\section{Indicators of increasing discipline, achievement and achievement of task implementation objectives}

In the housing and settlement department the structuring, supervision of buildings and billboards. Discipline of the government apparatus looks very good as informed by the head of the structuring, building supervision and advertisement boards that the discipline of his subordinates is good and the supervision of the field continues to be carried out even though there are 
still many complaints from the public regarding the availability of Infrastructure, Facilities, Public Utilities, Instantsi leaders must continue conduct supervision both directly and indirectly to his men on duty in the field. The lack of achievement and the lack of achievement of the target implementation of tasks and the many complaints from the public regarding the availability of infrastructure, facilities and housing utilities make evidence of less than optimal government supervision of housing developers (developers). In the development agenda that has been announced in 2016 2021 the Department of Housing and Settlements of the City of Banjarbaru, the target and the performance target to be achieved is to Improve the Quality of Basic Settlement Infrastructure. With the realization of budget absorption of $96.50 \%$ in 2017, the Department of Housing and Settlements of Banjarbaru City can be categorized as an institution whose activity level of achievement in absorbing the budget has met expectations.

In the scope of the Department of Housing and Settlements, Banjarbaru City the problems that arise are that the lack of optimal housing and settlement planning results in the development direction of development policy and development supervision, overlapping development action plans between sectors and does not focus on determining priorities in housing and settlement development further adds to spatial issues and building supervision. Considering the above, at this time in Banjarbaru City the preparation of the document for the Banjarbaru City Housing and Settlement Development and Settlement Planning document, slum data base document, Discussion on Spatial Planning that accommodates regional development, settlement development which is more intensive but still paying attention to the environment sustainable (sustainable development). One target of the Banjarbaru City Housing and Settlements Department is to increase the availability and quality of the housing environment and residential areas with a strategy to improve the management of infrastructure, facilities and housing utilities. In the coverage of a healthy and safe residential environment supported by infrastructure, facilities and utilities the Banjarbaru City Housing and Settlements Office targets a target of 15 percent in 2017 and 55 percent at the end of the 2016-2020 RPJMD, the target is quite good, the Program Work Indicators (Outcome) and Activities (Output) is expected to continue to increase so that the availability of infrastructure, facilities and utilities are met properly.

\section{Indicator of reduced abuse of authority}

The high number of community demands related to the unavailability of infrastructure, facilities and housing utilities to the government is the main issue of the government's weak supervision in using its authority, firmness is absolutely necessary for housing developers (developers) who do not comply with local regulations, housing and settlement services together with civil service police units as tools Regional enforcement is expected to be able to overcome problems related to Infrastructure, Facilities and Utilities that are not provided by housing developers, many of the unfulfilled housing facilities are clear evidence of the government's weak supervision of housing developers, strict sanctions in accordance with regulations must be upheld to housing developers who are fraudulent and do not want to comply with local regulations set by the government, it is hoped that in the future there will be no more abuse of authority by routinely providing counseling and technical guidance to the authorities. so that demands and complaints from the public regarding the availability of infrastructure, facilities and utilities are reduced and housing developers are obedient and orderly in carrying out development.

\section{Indicators of reduced leakage, waste and illegal fees}

Oversight by the government from the lowest level, namely the neighborhood committee, can examine the quality and quantity of cases of deviations carried out by housing developers, a good approach and positive directions can reduce deviations committed and are expected to make the community aware of the importance of availability Housing Infrastructure, Facilities and Utilities by housing developer. In related agencies, especially the housing and settlement department, can detect early on fraud, leakage and waste by the apparatus so that negative reports from the community can be reduced as functional monitoring reports and other monitoring reports and the level of error in carrying out the task is reduced. Effectiveness in managing government budgets must continue so that government programs can continue to touch and be useful in a sustainable manner for the community.

Illegal levies carried out by the apparatus to housing developers, both starting from the licensing process to monitoring development in the field, must be immediately followed up and "exterminated" because this besides having a negative impact on development also has fatal consequences for the community and unfavorable environmental conditions. Analysis of the optimization of government oversight in the availability of infrastructure, facilities and utilities to the indicators of supervision is set out in the following table. 


Table-1: Optimization of Government Oversight of the Availability of Infrastructure, Facilities and Utilities
\begin{tabular}{|l|l|l|}
\hline \multicolumn{1}{|c|}{$\begin{array}{c}\text { Oversight } \\
\text { Indicator }\end{array}$} & \multicolumn{1}{|c|}{ Results } & \multicolumn{1}{c|}{ Optimization } \\
\hline $\begin{array}{l}\text { Employee } \\
\text { Discipline }\end{array}$ & $\begin{array}{l}\text { Attendance and supervision } \\
\text { every day in the field }\end{array}$ & $\begin{array}{l}\text { Direct and indirect supervision in the availability } \\
\text { of Infrastructure, Facilities, Utilities housing }\end{array}$ \\
\hline Achievement & $\begin{array}{l}\text { The lack of achievement } \\
\text { because of the many complaints } \\
\text { from the public }\end{array}$ & $\begin{array}{l}\text { Increased Housing Development with } \\
\text { Infrastructure, Facilities and Utilities }\end{array}$ \\
\hline $\begin{array}{l}\text { Achievement of } \\
\text { Targets and Tasks } \\
\text { in Implementing } \\
\text { Tasks }\end{array}$ & $\begin{array}{l}\text { Increasing the effectiveness of } \\
\text { handling housing and structuring } \\
\text { and managing parks, cemeteries } \\
\text { and public street lighting }\end{array}$ & $\begin{array}{l}\text { Increased development effectiveness with } \\
\text { Infrastructure, Facilities and Utilities }\end{array}$ \\
\hline $\begin{array}{l}\text { Achievement } \\
\text { Results }\end{array}$ & $\begin{array}{l}\text { The realization of the budget } \\
\text { absorption of } 96.50 \% \text { in } 2017\end{array}$ & $\begin{array}{l}\text { Absorption of the entire budget for the } \\
\text { community }\end{array}$ \\
\hline Abuse of Authority & There is still a tendency & $\begin{array}{l}\text { There is no abuse of authority by conducting } \\
\text { direct supervision }\end{array}$ \\
\hline $\begin{array}{l}\text { Community } \\
\text { Demands }\end{array}$ & $\begin{array}{l}\text { There are still many demands } \\
\text { from the community }\end{array}$ & reduced community demands \\
\hline $\begin{array}{l}\text { Budget Leaks and } \\
\text { Waste }\end{array}$ & $\begin{array}{l}\text { There is still leakage and waste } \\
\text { Illegal levies }\end{array}$ & Lack of leakage and budget waste \\
\hline
\end{tabular}

Based on Article 1 General Provisions of Law Number 1 of 2011 Regarding Housing and Settlement Areas is a unified system consisting of housing development, housing, housing and settlement areas, maintenance and repair, prevention and improvement of quality of slums and slums, land supply, funding and financing systems, and the role of the community. Pursuant to Article 1 of Law Number 1 of 2011 concerning Housing and Settlement Areas, housing developers (developers) are business operators engaged in the implementation of housing and settlement areas. The housing developer in question must be a legal entity established by an Indonesian citizen whose activities are in the area of housing and settlement areas. This principle of partnership provides the basis for the implementation of housing and settlement areas to be carried out by the Government and Regional Governments by involving the role of business actors and the community, with the principle of mutual need, trust, strengthen and benefit that is carried out, both directly and indirectly.

In order for the implementation of the provision of infrastructure, facilities and utilities to run well, the government issues regulations and standards governing the procurement of infrastructure, facilities and public utilities in a housing environment that is regulated in Article 20 Paragraph (2) of Law Number 1 Year 2011 Concerning Housing and Settlements stating that housing as referred to in Paragraph (1) includes houses or public housing, facilities, and public utilities, Article 23 Paragraph (2) which states that housing planning as referred to in Paragraph (1) consists of house planning and design; and planning of public housing infrastructure, facilities and utilities, then Article 32 Paragraph (1) which states that housing development includes the construction of houses and public infrastructure, facilities and utilities; and improving the quality of housing and Article 134 on prohibitions in housing construction which states that everyone is prohibited from carrying out housing construction, which does not build housing in accordance with the agreed criteria, specifications, requirements, infrastructure, facilities and public utilities. While the obligations and responsibilities of housing developers are contained in Article 19 of Law No. 1 of 2011 concerning Housing and Settlement Areas which states that the implementation of housing and housing is carried out to meet the needs of housing as a basic human need for improvement and equitable distribution of people's welfare.

In supervising housing, the government coordinates or related agencies to see the physical condition of infrastructure, facilities and public utilities [8]. Supervision must touch two aspects, namely preventive supervision and repressive supervision. Preventive supervision is supervision that is carried out before implementation, that is, surveillance is carried out on something that is planned. Preventive supervision is mostly done through licensing mechanisms. Repressive supervision is supervision carried out after work or activities are carried out. In this case the Banjarbaru City government supervises the implementation of development carried out by the developer. 


\section{CONCLUSION}

Increased development of infrastructure, facilities and public utilities is marked by an increase in the population. Certainly demands the availability of representative housing land for the community. With regard to public safety and comfort, direct and indirect government supervision is needed. It is intended that complaints and reports from the public regarding the unavailability of infrastructure, facilities and housing utilities by housing developers can be minimized. Supervision practices carried out by the Banjarbaru City government can be maximized if they have sufficient resources. The resources in question are not only related to material but also human resources. Both must be maintained so that qualitative supervision performance is maximum. The effectiveness of government budget management must continue to be done so that government programs can continue to touch and be useful in a sustainable manner for the community. Supervision is more effective and efficient if the government apparatus in the villages and sub-districts are optimized and synergized with housing developers actively and regularly. Indirect supervision is carried out by following up on every report and complaint from the community at Wengga and Benawa Raya housing related to the unavailability of infrastructure, facilities and public utilities. Reports from field supervisors, both oral and written, can be accommodated for the sake of good implementation of development. Forms of preventive supervision already exist in the housing and settlement department in the form of licensing pamphlets that exist on the walls of the room as well as regional regulations governing the administration of housing and settlements in Banjarbaru City.

\section{REFERENCES}

1. Goheen, P. G. (1998). Public space and the geography of the modern city. Progress in Human Geography, 22(4), 479-496.

2. Platinga, A. (2003). Science and Secularism. Unpublished paper presented at Faith and the Challenges of Secularism at Princeton University, Princeton, New Jersey, 10.

3. Anderson, T., \& West, E. (2006). Open Space, Residential Property Values, and Spatial Context. Regional Science and Urban Economics. Edisi 36.

4. Irwin, E. (2002). The Effect of Open Space on Residential Property Values. Land Economic Journal.

5. Mulligan, G. (1991). Equality Measures and Facility Location. The Journal of the RSAI70.

6. Afifuddin, \& Ahmad, B. (2009). Metodologi Penelitian Kualitatif. Bandung: Pustaka Setia.

7. Sugiyono. (2014). Metode Penelitian Kuantitatif Kualitatif dan R\&D. Bandung : Alfabeta.

8. Sujamto. (1986). Beberapa Pengertian Dibidang Pengawasan. Jakarta: ghalia indah.

9. Undang-undang no 1 tahun 2011 perumahan dan permukiman. 